\title{
Intergenerational Translations in Uwe Timm's Am Beispiel meines Bruders
}

\begin{abstract}
Uwe Timm's autobiographical novel Am Beispiel meines Bruders (2003) epitomizes the wave of family narratives published in Germany around the turn of the millennium. Indeed, many scholars have noted that the narrator exhibits a nuanced and empathetic approach to his family's Nazi legacy. This article problematizes Timm's nuanced tone. I argue that he adopts different narrative strategies to discuss his brother, who volunteered for the SS-Totenkopfdivision at eighteen years of age, and his mother, who remains unnamed throughout the novel. Drawing on Itamar Even-Zohar's polysystem theory of translation, and more specifically on his concept of conservative and innovative repertoires, I argue that Timm translates stories about members of the war generation in a differentiated way, thereby producing distinct effects in each case. More specifically, I demonstrate that the narrator creates a rupture with his brother, subjecting his choice of words to scrutiny and following in the footsteps of the well-established Väterliteratur of the 1970s to the 1980s. Conversely, Timm strengthens his affiliation with his mother by avoiding an overly critical examination of her, focusing instead on her use of non-verbal and non-politically loaded language.
\end{abstract}

Keywords: family history, gender, generations, memory, Nazism, Uwe Timm

Uwe Timm's autobiographical novel Am Beispiel meines Bruders (2014 [2003]) delicately assesses family members involved in World War II as Nazi perpetrators and bystanders. Like many family narratives published in Germany around 2000, the narrator displays a "more measured understanding" (Finlay 2009, 202). ${ }^{1}$ While Timm empathizes with his family's war sufferings, he exposes its prejudice and connects it to German complicity, using a montage technique to attain this effect (Rossbacher 2005). The novel thus departs from the Väterliteratur [literature of the fathers] of the 1970s to the 1980s, which primarily foregrounds a conflict between the war and the post-war generation (Assmann 2006, 42-52; McGlothlin 2006, 215-227; Fuchs 2008, 28-33; Schmitz 2007b, 154; Baker 2012, 87).

1 Unless stated otherwise, all further references to Timm are to the first-person narrator of $\mathrm{Am}$ Beispiel meines Bruders.

Ә Open Access. (C) 2020 Mélanie Yœurp, published by De Gruyter. (c) BY-NC-ND This work is licensed under a Creative Commons Attribution-NonCommercial-NoDerivatives 4.0 License. 
However, I argue that the narrator does not contextualize his family members equally. My examination focuses on two less-studied characters. I claim that he adopts strategies that allow him to distance himself from his brother Karl-Heinz, who was eighteen at the time he volunteered for the SS-Totenkopfdivision, and subsequently died of leg wounds in 1943 during a battle in Ukraine. At the same time, Timm redeems his mother, who remains an unnamed housewife bystander during World War II. More specifically, the narrator describes his brother with the aim of creating critical distance, while he deploys a language based on the senses to soften the critique of his mother.

To illuminate Timm's different narrative strategies, I draw on the concept of conservative and innovative repertoires developed by Itamar Even-Zohar (1990, 21) in his polysystem theory of translation. I compare Timm to a translator who faces the choice of rendering a foreign text either by conforming to a pre-established literary repertoire in the target language, or by deviating from it and introducing new (formal) elements. In this framework, Timm describes his brother by recreating the trope of generational opposition as established in Väterliteratur, while subtly diverging from this topic when discussing his mother. In what follows, I first lay the foundation for considering intergenerational understanding as an act of translation within the polysystem paradigm. I then demonstrate how Timm's contextualization of his brother conforms to historical criticism, and thus contributes to a “conservative repertoire.” Finally, I discuss how the narrator contrastingly detaches his mother from a critical appraisal, thereby producing the impression of transparent understanding. This reading comes at a time when historians are demonstrating that women were involved in the war effort to various degrees, ${ }^{2}$ and ultimately draws attention to an effort to portray women complicit in National Socialism in a positive light.

Before framing intergenerational understanding as an act of translation, we first need to define "generation." Karl Mannheim proposes a sociological interpretation of this biological concept. He explains in his canonical article "Das Problem der Generation" (1964 [1923]) that members of the same generation are marked by similar stratifications of experience. In particular, the historical events they went through during their youth determine their perspective, which later coalesces into a natural worldview through which they interpret future experiences. As a result,

2 On the historiography of the role of racially privileged women in the Third Reich, see Herkommer (2005). 
a generation involves a common sense of normalcy based on shared points of reference. These points of reference cease to be taken for granted when a new generation questions them. Generations thus become visible against the foil of one another.

This rupture in terms of worldview is particularly visible in family stories and memories of World War II. The historical events are construed differently from one generation to another. According to Sigrid Weigel, the year 1945 represents a "break in the historical continuum leading to an entirely altered state of consciousness, re-establish[ing] a quasi-natural genealogy" (2002, 268). She argues that, after 1945, one can delineate the contour of a generation by identifying and contrasting the way individuals understand and remember World War II. Weigel further notes that these different interpretations follow the natural (biological) rhythm of generations. Younger non-Jewish Germans seek to distance themselves from the war generation which refuses to admit its guilt. ${ }^{3}$ This is evident in the stories from the Väterliteratur of the 1970s to the 1980s, where the sons condemn their fathers for being complicit in National Socialism.

However, this same post-war generation's interpretation of World War II is far from being monolithic. Harald Welzer, Sabine Moller, and Karoline Tschuggnall (2002) argue that the second - as well as the third - generation of Germans inaccurately remembered their parents and grandparents as victims of National Socialism, or wrongly assumed that their forebears resisted the Third Reich however they could. Both generations thus edited out unpalatable aspects of their family stories as a result of family loyalty and the erosion of historical consciousness. Furthermore, the intransigent tone of the 1968 generation gave way to a more empathetic approach. The latter compensates for an earlier, resolutely antagonistic attitude which, according to a growing discourse on German victimhood, repressed and marginalized Germans' war sufferings in order to avoid trivializing the experiences of the victims of National Socialism (Schmitz 2007a, 144-145).

In spite of this trend, intergenerational conflict remains a central topos. The literary scholar Susanne Vees-Gulani (2010, 62-64) remarks that it has become the paradigm in light of which literary commentators review texts, castigating narratives of victimhood for overshadowing discussion of the true victims of $\mathrm{Na}$ tional Socialism. To borrow Even-Zohar's terminology (1990, 21), a critical examination of the parents' Nazi legacy is the norm and thus constitutes a trope in the conservative repertoire, while narratives of victimhood deviate from it and therefore express an innovative repertoire. Drawing on Russian formalism, this Israeli scholar introduced these concepts as part of his polysystem theory in the 1970s to

3 For a study of the memories of children of Holocaust survivors, see Hirsch (2012). 
provide a historical perspective on the study of translations. He argues that translated literature is governed by social norms in a given culture at a given time: it forms a system within a larger literary system, which in turn is part of a cultural system. Even-Zohar thus contends that translation is not an ahistorical equivalence between a source and target language. Translators can render a text into another language by conforming to the characteristics of an established repertoire in the target literary system. Conversely, they can deviate from it by introducing new elements to the repertoire. Although polysystem theory posits in a problematic fashion that these different systems form a universal whole, it also helps us understand how narrators give form to their family stories, aligning with or deviating from pre-existing tropes recognized as canonical. ${ }^{4}$ By reproducing aspects of the canonical father-son confrontation, they reproduce a narrative of rupture. In contrast, deviating from it allows narrators to outline intergenerational continuity. I demonstrate below that Timm manipulates both narratives. On the one hand, he creates a generational opposition with his brother. On the other hand, he softens his critique of his mother by describing her in a timeless, sense-based language, thereby circumventing references to a historical context.

Timm brings the portrayal of Karl-Heinz closer to a "conservative," canonical narrative of rupture with the war generation. He scrutinizes his brother's choice of words in the hope of uncovering his ideological stance. His language becomes a possible telltale sign of a Nazi worldview, which feeds Timm's criticism of KarlHeinz. However, Timm's reliance on words alone does not prove very fruitful. The language the sibling uses in his journal and letters remains laconic and opaque to the narrator. The lack of context prevents the latter from offering a conclusive interpretation of the Nazi terminology he encounters:

Es war eine dieser Stellen, an denen ich früher innehielt, beim Weiterlesen zögerte. Könnte mit Läusejagd nicht auch etwas ganz anderes gemeint sein, nicht einfach das Entlausen der Uniform? Andererseits würde dann nicht dastehen 1 Tag Ruhe. Aber dann dieses: Viel Beute! Was verbirgt sich dahinter? Waffen? Warum dieses Ausrufezeichen, das sich sonst selten in seinen Notizen findet? (Timm 2014, 16)

[This was one of those passages where I would stop, hesitating to read on. Couldn't louse hunt mean not just delousing a uniform but something very different? On the other hand, if so he would not have said 1 day's rest. But then, that Plenty of loot!

4 For a contextualization of Even-Zohar's polysystem theory, see Gentzler (1993, ch. 5).

5 All italics in quotations from Am Beispiel meines Bruders and its translation are in the original. 
What exactly do the words conceal? Armaments? Why the exclamation mark, which is otherwise rare in his notes?] (Timm, trans. Bell 2005, 11)

This passage captures Timm's ambivalence, which pervades the whole novel. On the one hand, Timm questions the meaning of politically loaded terms, indicating his desire to tie his brother to an extralinguistic and historical context. On the other hand, his multiple questions illustrate his refusal to rush to a conclusion without further evidence, making his attempt to condemn his brother seem academic. For instance, he recognizes that Karl-Heinz's use of “delousing” is undoubtedly entrenched in Nazi ideology since it can euphemistically refer to the extermination of the Jews in Nazi propaganda - a meaning endorsed by "Viel Beute!" Yet, it might also describe the actual act of delousing, as the temporal information "1 Tag Ruhe" invites the reader to believe.

Beyond carefully interpreting Karl-Heinz's language, Timm seems to harbour hope that his brother did not embrace Nazi ideology. Some wording appeals to Timm, who wishes to find traces of his brother's disillusionment in the journal and letters he left behind. Indeed, Timm remarks that Karl-Heinz jestingly suggests, in a mail dated 25 July 1943, that he wanted to pick up one of the young ladies he saw near Konstantinowka in Ukraine: "darum brauchst Du es nicht mit der Angst zu tun kriegen, ich lache mir ja doch eine an - äh ich meine, ich lache mir doch keine ..." [but you don't need to worry, I'll try to pick one of them up - no, I mean, I won't try to pick one of them up ...] (Timm 2014, 91; trans. Bell 2005, 83) The narrator's inclusion of such information reflects his desire to showcase a brother who may have wished to transgress the interdiction against "Aryan" people mixing with allegedly inferior Slavic people. From this vantage-point, analysing Karl-Heinz's choice of words functions as a double-edged sword for Timm when it comes to tracing his brother's ideological contours.

Hence, Timm does not limit himself to deciphering Karl-Heinz's choice of words. He also investigates the assumptions underpinning his use of Nazi vocabulary and omissions. This wider contextualization renders his brother more palpable to historical enquiry, in particular because it exposes his blind spots. As Assmann (2006, 44-47) and McGlothlin (2006, 221-226) have noticed, Timm is aware that Nazi ideology had infiltrated the German language during the war period, shaping the population's sense of normalcy. In his view, the absence of Nazi jargon from his brother's writings reflects the fact that he had already assimilated the concepts. Naming them would thus become redundant: "In dem Tagebuch des Bruders findet sich keine ausdrückliche Tötungsrechtfertigung, keine Ideologie, wie sie in dem weltanschaulichen Unterricht der SS vorgetragen wurde. Es ist der normale Blick auf den Kriegsalltag" [I find no express justification of killing in my brother's diary, nothing resembling the ideological instruction given to the 
SS. It is just a normal view of daily life in war] (Timm 2014, 94; trans. Bell 2005, 85). By highlighting the ideological principle underlying Karl-Heinz's language, Timm situates his choice of words and omissions in an ideological framework where they are highly meaningful, regardless of whether his brother consciously adhered to a Nazi worldview. According to Taberner $(2005,159)$, the narrator's historicization of the war generation's perspective and values challenges its universal and self-evident character. This narrative strategy aims to create distance from the brother's perspective, rather than to recreate it (Sathe 2006, 49-71). Indeed, the fact that Timm stops wondering about the meaning behind words indicates that he is no longer interested in what intentions his brother had. Instead, he directly addresses the assumption behind the language, thereby finding a foothold to argue against Karl-Heinz.

Ein Fressen für mein $M G$ : ein russischer Soldat, vielleicht in seinem Alter. Ein junger Mann, der sich eben die Zigarette angezündet hatte - der erste Zug, das Ausatmen, dieses Genießen des Rauchs, der von der brennenden Zigarette aufsteigt, vor dem nächsten Zug. An was wird er gedacht haben? An die Ablösung, die bald kommen musste? An den Tee, etwas Brot, an die Freundin, die Mutter, den Vater? [...] An was wird er gedacht haben, der Russe, der Iwan, in dem Moment? Ein Fressen für mein MG. (Timm 2014, 17)

[Fodder for my MG: a Russian soldier, perhaps his own age. A young man who had just lit a cigarette - drawing on it for the first time, breathing out, relishing the smoke rising from the burning cigarette before inhaling again. What was he thinking about? The troops who would soon arrive to relieve them? Tea, a piece of bread, his girlfriend, his mother, his father? (...) What will he have been thinking, the Russian, the Ivan, at that moment? Fodder for my MG.] (Timm, trans. Bell 2005, 13)

In his diary, Karl-Heinz objectifies the Russian soldier by referring to him with the pejorative noun "Ivan." Timm contrasts his own humanity with his brother's lack of it, which probably stems from anti-communist indoctrination under the Third Reich (Rossbacher 2005, 252-253). He captures the victim's possible sensations and thoughts in minute detail, thus drawing our attention to his brother's lack of empathy. By reproducing what may have been the Russian's point of view, Timm refuses to stereotype him. He imagines his thoughts and feelings, which highlights that the soldier was in a similar position to his brother. This juxtaposition is fruitful because the narrator addresses the context in which Karl-Heinz's language - and actions made sense, arriving at a justification for effecting a rupture with his brother.

While Timm narrows down his framing of Karl-Heinz to situate him in a historical analysis, ultimately recreating the structure of a generational opposition, he de- 
taches his mother from this narrative template. He instantiates an intimate proximity to her in his writing, thereby bringing his portrayal of her closer to an innovative repertoire. The narrator's desire for an affiliation with her is announced by the fact that he only calls her "meine Mutter" [my mother]. This designation translates a wish to protect her identity. Conversely, men in the novel are identified by their name, and their actions are traceable in archives and documents in such a way that they can be situated in a greater historical framework. ${ }^{6}$

This longing for affiliation does not mean that Timm entirely glosses over the role of his mother as a bystander during the war. He acknowledges it, but tempers it by suggesting that she has gained critical distance. Thus, he concedes that she protected Karl-Heinz's moral integrity by complacently distinguishing the murderous Einsatzgruppen from the SS, which she considered "eine normale Kampftruppe” [a normal fighting unit] (Timm 2014, 20; trans. Bell 2005, 15). At the same time, he notes that she was opposed to her eldest son's decision to volunteer for the Waffen-SS. Likewise, Timm remarks that his mother followed the model of the males in her family. After the war, she voted for a leftwing party and went to the opera, theatre, and museums on Timm's recommendation. Yet he depicts his mother as having a pessimistic view of politics: "Sie ging wählen, aber immer mit der Bemerkung, die machen doch, was sie wollen” [She voted in elections but always with the comment: They'll do as they like anyway] (Timm 2014, 46; trans. Bell 2005, 40). It is precisely this lucidity that may justify Timm's wish to relate to her. Indeed, this figure contrasts with the father, who is still imbued with masculine and military values, even after the war. She thus constitutes "the counterpoint to the ideological rigidity of the $p a$ ter familias" (Fuchs 2008, 33).

Nevertheless, Timm remains silent about her relative passivity during the war. In particular, he does not explicitly state to what extent it may have contributed to the prevalence of militaristic ideas at home. It may have allowed the father's values to pervade family life, ultimately leading Karl-Heinz to join the Waffen-SS at the age of eighteen. Claudia Koonz (1987) was one of the first historians to highlight the relationship between the home and the war front. In a groundbreaking fashion, she challenged the contemporary feminist theory that all women under the Third Reich were victims of misogynist policies, triggering what is known as the Historikerinnenstreit [quarrel among historians of women] in the late 1980s. Koonz views women at home as critical in supporting the war effort

6 While much remains to be said about the aspect of gender, the scope of this article does not allow me to develop my argument beyond viewing family narratives in light of Even-Zohar's two repertoires. 
by preserving "an illusion of love in an environment of hatred" $(1987,17)$, which enabled men to fight on the war front. ${ }^{7}$ Timm's scant critical attention to his mother during the war, coupled with his focus on her in the post-war period, lays the foundation for him to consider this woman as a positive figure.

To strengthen his affiliation with the mother - and further circumvent a historical contextualization - Timm seeks refuge in accounts that entrench his relationship with her in the senses. This allows him to align his perspective with hers without having to subject her stories to an extralinguistic analysis as he did with his brother. In over one and a half pages, he tells how his mother still captures his imagination, as she repeats one more time how Karl-Heinz got lost one night on his way to enrol in the Waffen-SS:

1942, im Dezember, an einem ungewöhnlich kalten Tag, spätnachmittags, war er nach Ochsenzoll, wo die SS-Kasernen lagen, hinausgefahren. Die Straßen waren verschneit. Es gab keine Wegweiser, und er hatte sich in der einbrechenden Dunkelheit verlaufen, war aber weiter an den letzten Häusern vorbei in Richtung der Kasernen gegangen, deren Lage er sich auf dem Plan eingeprägt hatte. Kein Mensch war zu sehen. Er geht hinaus ins offene Land. Der Himmel ist wolkenlos, und nur über den Bodensenken und Bachläufen liegen dünne Dunstschwaden. Der Mond ist eben über einem Gehölz aufgegangen. Der Bruder will schon umkehren, als er einen Mann entdeckt. Eine dunkle Gestalt, die am Rand der Straße steht und über das verschneite Feld in Richtung des Mondes blickt. (Timm 2014, 11-12)

[In December 1942, late in the afternoon of an unusually cold day, he went out to Ochsenzoll, where the SS had their barracks. Snow had settled on the roads. There were no signposts, and he had lost his way in the gathering dusk, but he went on past the last houses toward the barracks. He had noted their position on the map. Not a soul in sight, and he sets out into open country. The sky is cloudless, with a wispy mist only above the hollows in the ground and the streambeds. The moon has just risen above a stand of trees. My brother is about to turn back when he sees a man, a dark figure standing by the roadside, looking across the snow-covered field and up at the moon.] (Timm, trans. Bell 2005, 7)

Unlike the passages in which Timm talks about his brother, the narrator here does not comment on the language of his mother's retelling. Instead, this excerpt demonstrates that his and her viewpoints converge, securing a sense of intergenerational continuity, through an emphasis on the senses. This passage does not cannot - trace the interventions and additions in the narrative despite the precision of the details presented. The information that describes perception makes it particularly hard to tell whose (actual or imagined) vantage-point is rendered in

7 As early as in the late 1980s, historians have started complicated this perspective by considering women as a heterogeneous category composed of individuals with different backgrounds, life stages, marital status, social classes, occupations, and so on. For instance, see Schwarz, Mailänder, Joshi, and Harvey. 
the mother's story. It could be Karl-Heinz's account as he told it the first time, his mother imagining or embellishing what her eldest son must have perceived, or Timm reimagining as a child or as an adult the scene his mother described. However, this rich depiction stimulates the imagination. The minute details of the scene - such as the temperature, the quality of the light, the surrounding environment - help Timm visualize his brother's whereabouts, culminating in the narrator's perspective merging with his brother's and/or mother's with the passage from the past to the present tense. The senses acquire here an essential role in conveying a seamless understanding between members of different generations, thus ensuring a sense of continuity. In other words, they give the illusion that a story has a constant, absolute meaning which can be faithfully transposed from one individual's understanding to another, without the inference of generational Selbstverständlichkeit.

Timm strengthens the impression of a transparent understanding with his mother by thematizing non-verbal communication with his parent. The specific sign language and gestures the two protagonists use do not arbitrarily refer to an extralinguistic reality, as was the case with the words chosen by Karl-Heinz. According to Timm, the brother's language denotes a predetermined, sometimes opaque reality, prompting the narrator to unravel its meaning in light of history. In contrast, the tactile signs exchanged between Timm and his mother do not mean anything. Instead, they point to a situation which has yet to be interpreted:

Sie lag da, halbseitig gelähmt, ein Lallen kam aus ihrem Mund, aber mit der Rechten, mit den Fingern drückte sie mir die Hand, dreimal kurz. Es war das Zeichen, mit dem wir uns verständigten, wenn ich als Kind mit ihr durch die Stadt ging und wir uns wortlos auf etwas aufmerksam machen wollten: eine Frau mit einem sonderbaren Krähenhut, der Mann mit dem nervösen Zucken im Gesicht. (Timm 2014, 113)

[She lay there paralyzed down one side, her mouth making babbling sounds, but she pressed my hand three times, briefly, with the fingers of her own right hand. It was the signal between us when, as a child, I used to walk through town with her and there was something we wanted to point out to each other without speaking: a woman wearing a funny feathered hat, a man with a nervous tick.] (Timm, trans. Bell 2005, 103-104)

This way of communicating challenges the passage of time materialized in the mother's physical decline and her inability to articulate words. Her signals are in themselves devoid of meaning, and cannot be interpreted in light of a specific historical or ideological context. The mother does not run the risk of using words that can be politically loaded. Because the mother has been getting her son's attention with non-verbal cues since Timm was a child, she does not rely on a pre-established relation between a signifier and a signified. Instead, the meaning she refers to has to be created each time the two protagonists communicate in this fashion. 
This requires them to align their perspectives and to pay heed to their environment anew. The meaning cannot be bound to a particular context; it is constantly shifting. This configuration between the two characters bridges the generational gap and secures an enduring sense of continuity. The perpetual need to renew perspective by using hand signals justifies Timm's omission of a critique of his mother's language and choice of words.

The approach I have taken here complicates the claim that Timm's engagement with his family's Nazi past is evenly nuanced. Through the lens of Even-Zohar's (1990) polysystem theory of translation, and more specifically his concept of conservative and innovative repertoires, I argue that Timm can be understood as an intergenerational translator who connects the stories of his brother and his mother to these two repertoires respectively. This line of enquiry allows us to account for the narrator's strategies in distancing himself from or aligning himself with family members of the war generation. Timm seeks to reproduce an intergenerational rupture, which is characteristic of a conservative repertoire shaped by the Väterliteratur of the 1970s to the 1980s, when he discusses his sibling. He submits KarlHeinz's writings to historical criticism, and inscribes the words chosen by KarlHeinz in an ideological framework, so that he can leverage a careful and critical account of him. In contrast, he detaches his mother from a specific historical context, thereby contributing to an innovative repertoire. By focusing on her way of communicating through the senses and bodily signs, the narrator shapes a figure with whom he can enter into a dialogue unaffected by ideology. Timm's differentiated approach not only invites future critical attention to the role of gender in dealing with the Nazi legacy in family narratives, but also raises questions about the individual and collective memory of mothers, and to what extent this remembrance obscures their role in enabling Nazi ideas to spread during World War II.

\section{Works cited}

Assmann, Aleida. Generationsidentitäten und Vorurteilsstrukturen in der neuen deutschen Erinnerungsliteratur. Vienna: Picus, 2006.

Baker, Gary L. "The Involution of History in Uwe Timm's Am Beispiel meines Bruders." Monatshefte 104.1 (2012): 86-101.

Even-Zohar, Itamar. “Polysystem Studies.” Poetics Today 11.1 (1990): 9-26.

Finlay, Frank. “Jackboots and Jeans': The Private and the Political in Uwe Timm's Am Beispiel meines Bruders." Germans as Victims in the Literary Fiction of the Berlin Republic. Ed. Stuart Taberner and Karina Berger. Rochester: Camden House, 2009. 191-204. 
Fuchs, Anne. Phantoms of War in Contemporary German Literature, Films and Discourse:

The Politics of Memory. Basingstoke: Palgrave Macmillan, 2008.

Gentzler, Edwin. Contemporary Translation Theories. London: Routledge, 1993.

Harvey, Elizabeth. Women and the Nazi East: Agents and Witnesses of Germanization. New Haven: Yale University Press, 2003.

Herkommer, Christina. Die Rolle von Frauen im Nationalsozialismus im Spiegel des Diskurses der Frauen- und Geschlechterordnung. Munich: M Press, 2000.

Hirsch, Marianne. The Generation of Postmemory: Writing and Visual Culture after the Holocaust. New York: Columbia University Press, 2012.

Joshi, Vandana. Gender and Power in the Third Reich: Female Denouncers and the Gestapo (1933-45). Basingstoke: Palgrave Macmillan, 2003.

Koonz, Claudia. Mothers in the Fatherland: Women, the Family, and Nazi Politics. New York: St. Martin's Press, 1987.

Mailänder, Elissa. Gewalt im Dienstalltag: Die SS-Aufseherinnen des Konzentrations- und Vernichtungslagers Majdanek. Hamburg: Hamburger Edition, 2009.

Mannheim, Karl. "Das Problem der Generationen.” 1923. Wissenssoziologie: Auswahl aus dem Werk. By Mannheim. Berlin: Luchterhand, 1964. 509-565.

McGlothlin, Erin H. Second-Generation Holocaust Literature: Legacies of Survival and Perpetration. Rochester: Camden House, 2006.

Rossbacher, Brigitte. “Cultural Memory and Family Stories: Uwe Timm's Am Beispiel meines Bruders." Gegenwartsliteratur: A German Studies Yearbook 4 (2005): 238-258.

Sathe, Nikhil. “'Ein Fressen für mein MG': The Problem of German Suffering in Uwe Timm's Am Beispiel meines Bruders." Victims and Perpetrators: 1933-1945: (Re)Presenting the Past in Post-Unification Culture. Ed. Laurel Cohen-Pfister and Dagmar Wienroeder-Skinner. Berlin: De Gruyter, 2006. 49-71.

Schmitz, Helmut. "Introduction: The Return of Wartime Suffering in Contemporary German Memory Culture, Literature and Film." A Nation of Victims? Representations of German Wartime Suffering from 1945 to the Present. Ed. Schmitz. Amsterdam: Rodopi, 2007a. 1-30.

Schmitz, Helmut. "Representations of the Nazi Past, II: German Wartime Suffering." Contemporary German Fiction: Writing in the Berlin Republic. Ed. Stuart Taberner. Cambridge: Cambridge University Press, 2007b. 142-158.

Schwarz, Gudrun. Eine Frau an seiner Seite: Ehefrauen in der „SS-Sippengemeinschaft“. Hamburg: Hamburger Edition, 1997.

Taberner, Stuart. German Literature of the 1990s and Beyond: Normalization and the Berlin Republic. Rochester: Camden House, 2005.

Timm, Uwe. In My Brother's Shadow: A Life and Death in the SS. Trans. Anthea Bell. New York: Farrar, Straus and Giroux, 2005.

Timm, Uwe. Am Beispiel meines Bruders. 2003. 2nd ed. Cologne: Kiepenheuer \& Witsch, 2014. Vees-Gulani, Susanne. “Between Reevaluation and Repetition: Ulla Hahn's Unscharfe Bilder and the Lasting Influence of Family Conflicts about the Nazi Past in Current Literature of the 1968 Generation." Generational Shifts in Contemporary German Literature. Ed. Laurel CohenPfister and Vees-Gulani. Rochester: Camden House, 2010. 56-76.

Weigel, Sigrid. “'Generation' as a Symbolic Form: On the Genealogical Discourse of Memory since 1945." The Germanic Review: Literature, Culture, Theory 77.4 (2002): 264-277.

Welzer, Harald, Sabine Moller, and Karoline Tschuggnall. Opa war kein Nazi: Nationalsozialismus und Holocaust im Familiengedächtnis. Frankfurt am Main: Fischer, 2002. 
Mélanie Yœurp completed her doctoral studies in German Studies at the University of Wisconsin-Madison. She came to the US as a Fulbright Scholar after earning her MA from the Universität Bonn and Université Paris-Sorbonne. Her research explores the figures of Nazi perpetrators and bystanders in contemporary German family ego-documents, with a focus on the mother figure. 